\title{
Communicative Leadership, Working Environment and Employees' Extra Role Performance 'Providing Service': A Case Study of South Jakarta Matahari Department Stores
}

\author{
Endah Setyowati \\ London School of Public Relation, Communication \& Business Institute Post Graduate Program \\ Jl KH Mansyur Kav 35, Jakarta Pusat 10220, Indonesia
}

\begin{abstract}
Studies examine how communicative leadership influences employees' extra role performance, and the influence of working environment on employees' performance in the retail industry, both of which independently and collectively are rarely discussed. Competition in retail industries is getting tougher therefore the aim of this paper is to help companies improve their employees' extra role performance which is providing service to customers by applying good communicative leadership and behavioral / non-physical working environment.A quantitative method study was conducted to address the research statements: leader communication behaviors / communicative leadership influences employees' behavior performance. Behavior working environment factors influence the millennial front liners' behavior performance which is providing excellent service to customers. Communicative leadership and behavior working environment collectively influence the employees' behavior performance. Literatures on Communicative Leadership, Working Environment, and Service Excellence were used to guide the research.The research findings are: Communicative Leadership behaviors influenced 25.1\% of Employees extra role Performance. Employee Performance was $48 \%$ influenced by Behavior Working Environment. Communicative Leadership and Working Environment collectively influenced 51.2\% of Employee Performance. The case study research focuses on the influences of communicative leadership and working environment on employees' extra role performance: providing service excellence. This quantitative research article can contribute and extend the discussion on the theory of communicative leadership, working environment, and enrich the notion of employees' performance specifically in regard to service excellence
\end{abstract}

Keywords: Communicative Leadership, Working Environment, Employee Performance, and Service Excellence. DOI: $10.7176 / \mathrm{EJBM} / 12-20-01$

Publication date:July $31^{\text {st }} 2020$

\section{Introduction}

Retail industry has reached its competition peak, especially department stores in Indonesia where products offered are hardly different from one another. To win the competition in the industry, stores need to have a differentiation and it depends on the service delivery that employees provide. No matter how good the products are, or how nice the stores look, if the people in the stores serve the customers in an ordinary way or even in a bad or inappropriate manner, sooner or later the customers will leave and never come back. Therefore, stores need to have good quality of front liners who are empowered, well trained, knowledgeable of what they are doing, task and customer oriented, full spirited and enthusiastic to stay and win the battle. In achieving the success leaders play a very crucial part. They ensure front liners to deliver service excellence, and yet too many service providers are under led because the service leadership is insufficient as most of the time leaders are not in the field to coach, praise, correct or observe their team. Based on Manager on Duty (MOD) Report, the index of MOD availability in the field of research object was only 63 meaning poor according to the Matahari Department Store standard (2017 Mystery Shopping Report, 2018). This condition caused leaders to provide insufficient service leadership. In terms of the working environment, Alex, (Matahari Department Stores Regional Manager, February 6, 2019) stated four dimensions of the working environment that became management's priorities in improving store operating excellence were goal setting, mentoring / coaching, performance feedback, and supervisor support. Unfortunately, the result of the pre survey conducted by the researcher showed only goal setting had a good index (based on MDS standard).

Besides the above problems phenomena, the index of the stores was still poor (68.8) and front liners / people index was worse (67.9) based on a 2017 Voice of Customers Report (2017 Voice of Customers Report, 2018) also underline the research.

The researcher chose Matahari Department Stores (MDS) as the research object because they are currently the biggest fashion retailers in Indonesia whose gross sale was IDR 17.824,9. Its net income of IDR 1.097,3 consists of $37.4 \%$ direct purchase (DP) products and $62.6 \%$ consignment products (CV). 159 MDS are present in 75 cities from Papua to Aceh with a total of 992.105 meter square (2018 Annual Report PT Matahari Department Store Tbk, 2019). Java stores contributed the biggest sales which was $61.8 \%$ compared to other regions as most of the stores were located in Java (2017 Annual Report Matahari Department Store, 2018). 
The objectives of the research are to:

a. Test whether communicative leadership behaviors that are also reflected in working environment articles influence the employees' behavior performances.

b. Investigate whether working environment factors that involve interaction between leaders and followers influence front liners' behavior performance which is providing service excellence to customers.

c. Test whether communicative leadership behavior and behavior working environment collectively influence MDS employees' behavior performances.

The scope of research discussed communicative leadership behaviors and limited working environment factors are to four only as needed by the company as per mentioned by the MDS Regional Manager / General Manager in the interview.

\section{Literature Review}

Working environment is shaped and influenced by the organization leaders and communication applied by the employee (Johansson, Miller, \& Hamrin, 2014), while "communicative leadership leads to higher levels of individual performance...higher level of performance at the unit level" (Johansson, Miller, \& Hamrin, 2011). Working environment positively affects employees' performance but behavioral working environment has a greater effect on the employees' performance (Haynes, 2008; Leblebici, 2012). Job performance is the way how front liners perform their work such as dealing with customers (Rashid, Sah, Ariffin, Ghani, \& Yunus, 2016). It is believed that all types of extra-role behavior performance contribute to the organization's performance (Podsakoff, Mackenzie, Paine, \& Bachrach, 2000).

\subsection{Communicative Leadership}

The concept of communicative leadership was developed in Sweden in the late 1990s in response to business development environment (Högström et al. 1999 cited by Johansson, 2011). Communicative Leadership is influenced by two communication approaches that focus on transmission of information and formation of meaning (Johansson, Miller, \& Hamrin, 2011). In tradition view, communication in leadership is one way where leaders are sending the message and employees understand the message and act on it. As the concept developed, transmission view that was used by LMX theory as a guidance, improved to sense making which communication in leadership is a dynamic and circular interaction where both parties leaders and employees actively participate (Johansson, Miller, \& Hamrin, 2011). Then we can define communicative leader as "one who engages employees in dialog, actively shares and seeks feedback, practices participative decision making, and is perceived as open and involved" (Johansson, Miller, \& Hamrin, 2011). Leader communication behaviors that are applied in organizational context are classified into four categories or called profile of center communication behaviors (Johansson, Miller, \& Hamrin, 2011):

a. Initiating structure: for individual employees, leaders have to set goals and expectation, do planning and allocate tasks. While for the team they have to define a mission for the unit, do planning and allocate tasks, set goals and expectations for the unit.

b. Facilitating work: for individual employees, leaders have to coach and train, and give performance feedback, for the group level leaders have to provide timely and effective feedback, engage employees in problem solving and decision making.

c. Relational dynamic: for both individuals and teams, leaders have to be open as well as approachable, good listeners and, trustworthy. They also have to display supportive behavior and constructive approach on conflict-full issues.

d. Representing employees and the unit: Leaders have to be able to apply upward influence and get resources from upper management. While for the unit leaders have to actively monitor opportunities and threats, build good networking internally and externally, manage the boundaries in working with other units as to protect the unit mission, and provide resources for the unit.

\subsection{Working Environment}

Front liners' good behavior performance cannot be taken for granted, they need to have good working conditions in order to be able to perform well, as a positive and supportive working environment will encourage and enable employees to perform effectively (Oswald, 2012). Working environment (WE) is defined as "a concept that encompasses the physical aspects, psycho-social and organizational surrounding of work" (Busck, Knudsen, \& Lind, 2010) and the surrounding place in which a person works and interacts with others professionally and socially (Ollukkaran \& Gunaseelan, 2012). Stallworth \& Kleiner (1996) emphasized that WE is divided into two categories: physical which consists of components that relate an employee to his or her ability to connect with his or her office environment, such as ventilation, circulation and space. Secondly, non-physical or behavior which consists of components that relates to his or her interactions with colleagues such as social and work interactions. The researcher will only discuss behavior factors of WE as stated in the introduction such as goal setting, performance 
feedback, supervisor support, and mentoring / coaching.

a. Goal Setting: Goal setting is one of the tools to attract employees' motivation as it is to guide their behavior and motivate them to perform better (Leblebici, 2012). Effective goals will help to gain commitment from both parties: the organization and the employees which results in people doing more than required and eventually it will increase performance (Erez, Earley, \& Hulin, 2017). Leblebici summarized that effective goals should be specific not generalized ones, difficult not easy ones, and should be accepted by the group. It is necessary to have frequent and relevant feedback, and this should be done with open communication (2012).

b. Performance Feedback: Performance feedback is an information given by an immediate supervisor or management on how an employee performs (Chandrasekar, 2011). The information can be both positive feedback meaning what an employee has been doing right, as well as feedback on what requires improvement (Oswald, 2012). Frequent or regular feedback and relevant feedback will create effectiveness in the employees' job activities. According to Prue \& Fairbank performance feedback can be done in daily, weekly, bi \& tri weekly, or on a monthly basis (1981). Based on their study, effective feedback can be done from a short glance or an extensive analysis, privately or publicly (which has greater effects), in a written, verbal, mechanical or self-recorded form (Prue \& Fairbank, 1981). However, when feedback is not well accepted by employees, it would have negative consequences such as demoralized or unperformed state (Modaff, DeWine, \& Butler, 2007). They also mentioned that feedback as a form of communication between members of an organization covers task guidance, personal guidance and other guidance if any both implicitly and explicitly (Modaff, DeWine, \& Butler, 2007).

c. Supervisor Support: According to Burke, Michael, Borucki \& Hurley supervisor support is "the degree to which employees perceive that supervisors offer employees support, encouragement and concern" (1992). Supervisors who are concerned and supportive of their subordinates or employees' work by being helpful, supportive and trust worthy in the work climate, can be also categorized as supervisor support (Yoon, Beatty, \& Suh, 2001).

d. Mentoring / Coaching: Douglas (1997) defines mentoring as "an intense relationship in which a senior person oversees the career development and psychosocial development of less-experienced person". While coaching is a short and more focus form of mentoring that relates to job task, skills, and performed by giving instruction, demonstration and high impact feedback (Hopkin-Thompson, 2000).

\subsection{Employee Performance: Service Excellence}

The performance of employees is measured by the output they produce (Tetteh, Asiedu, Odei, Afful, \& Akwaboah, 2012). Front liners' performance is measured by two things: outcome performance which generate $\$$ (money) for the company and behavior performance which is providing service to customers and store activities as well as knowledge and skills (Yap, Bove, \& Beveland, 2009). One of the extra-role behavior performance that Podsakoff, Mackenzie, Paine, \& Bachrach (2000) identified is the helping behavior and it relates to providing service to customers voluntarily. Hence, front liners' extra role behavior performance is generated from their daily activities which is interacting with customers to provide service excellence.

In measuring front liners' service to customers, the researcher uses Service Excellence a concept of the Johnston model in which four factors are involved: a. delivering the promise: the company through employees do what they say and the service is delivered consistently, b. providing a personal touch: the front liners treat customers like individuals, sales staff know customers without them having to tell them, c. going the extra mile: the front liners anticipate customers' need and they fall over themselves to help customers, and d. dealing with problems and queries: employees are happy and willing to sort things out when there is a problem (Johnston, 2004) and those factors are used by the writer to measure the service provided from an employees' point a view.

Figure 1: Johnston Model of Service Excellence

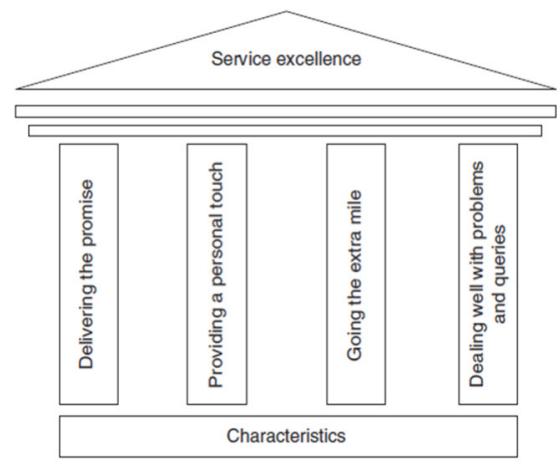

Source: (Johnston, 2004) 


\subsection{Conceptual Framework}

Figure 2: Conceptual Framework

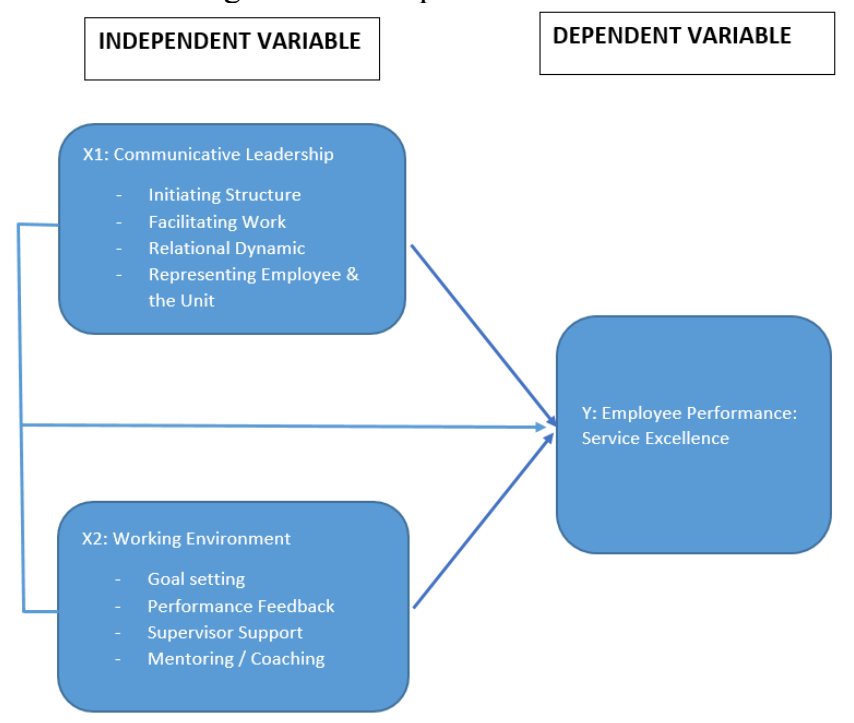

The conceptual framework above explains the communicative leadership behaviors and behavior working environment that influence front liners job performance which is providing service excellence.

Ha1. Communicative leadership behaviors influence employee behavior performance which is providing service excellence to customers

Ha2. Non-physical working environment factors influence the front liners' behavior performance which is providing service excellence to customers

Ha3. Communicative leadership and behavioral working environment influence front liners' behavior performance which is providing service excellence

\section{Research Method}

Using cross-sectional surveys, the study applied quantitative methodology, where SPSS for Windows version 22 was used to process the data.

Primary Data: gathered from the questionnaires or surveys conducted in five South Jakarta stores of Matahari Department Stores both in the forms of group administration and personal interviews. Secondary data such as 2017 Service Quality Index (SQI) Omnibus Survey Report, 2017 Know Your Customer Report, 2017 Voice of Customer Report, 2017 Mystery Shopping Report, 2017 and 2018 Annual Reports.

Population and Sampling: MDS front liners population in the selected five stores (MDS Kalibata, MDS Pejaten Village, MDS Citos, MDS Kemang Village, and MDS Blok M Plaza) was 1,117. Simple random sampling that was used applied Slovin's formula in determining the number of respondents: $1,117:(1+(1,117 \times 0.0004))=$ 772. The margin error tolerated was $2 \%$ so the number of the sample was 772 front liners and derived from MDS Kalibata: 95, MDS Citos: 242, MDS Pejaten Village: 245, MDS Kemang Village: 69, and MDS Blok M: 120. While in deciding which working environment factors to be studied the researcher conducted an interview with the Regional Manager / General Manager.

\section{Result and Analysis}

The researcher has already done the pre-test of 30 respondents in South Jakarta to test the validity and reliability of the questionaires. The stores tested are: MDS Kalibata 5 people, MDS Citos 10 people and MDS Pejaten 15 people.

\subsection{Validity Test}

Creswell (2012) defines validity as "the degree to which all of the evidence points to the intended interpretation of test scores for the proposed purpose". Validity shows how far the measurement chosen can measure an item that is being measured. The question or indicator of the instrument can be categorized significant or valid if the calculated value $\mathrm{r}$ (correlation coefficient) is positive and higher than the table value which is 0.05 (Priyatno, 2017). 
Table 1: Communicative Leadership variable and Working Environment variable validity result

\begin{tabular}{|l|l|l|l|l|}
\hline Variable & Questions & $\begin{array}{l}\text { Calculated } \\
\mathbf{r}\end{array}$ & $\begin{array}{l}\text { Tabulated } \\
\mathbf{r}\end{array}$ & Note \\
\hline X1.1 & IS1 & 0.883 & 0.134 & Valid \\
\hline & IS2 & 0.868 & 0.134 & Valid \\
\hline & IS3 & 0.878 & 0.134 & Valid \\
\hline X1.2 & FW1 & 0.886 & 0.134 & Valid \\
\hline & FW2 & 0.902 & 0.134 & Valid \\
\hline & FW3 & 0.859 & 0.134 & Valid \\
\hline X1.3 & RD1 & 0.892 & 0.134 & Valid \\
\hline & RD2 & 0.920 & 0.134 & Valid \\
\hline & RD3 & 0.929 & 0.134 & Valid \\
\hline X1.4 & RE1 & 0.918 & 0.134 & Valid \\
\hline & RE2 & 0.939 & 0.134 & Valid \\
\hline & RE3 & 0.930 & 0.134 & Valid \\
\hline X2.1 & GS1 & 0.757 & 0.134 & Valid \\
\hline & GS2 & 0.902 & 0.134 & Valid \\
\hline & GS3 & 0.882 & 0.134 & Valid \\
\hline & GS4 & 0.891 & 0.134 & Valid \\
\hline & GS5 & 0.682 & 0.134 & Valid \\
& & & &
\end{tabular}

\begin{tabular}{|l|l|l|l|l|}
\hline X2.1 & GS1 & 0.757 & 0.134 & Valid \\
\hline & GS2 & 0.902 & 0.134 & Valid \\
\hline & GS3 & 0.882 & 0.134 & Valid \\
\hline & GS4 & 0.891 & 0.134 & Valid \\
\hline & GS5 & 0.682 & 0.134 & Valid \\
\hline X2.2 & PF1 & 0.873 & 0.134 & Valid \\
\hline & PF2 & 0.756 & 0.134 & Valid \\
\hline & PF3 & 0.814 & 0.134 & Valid \\
\hline & PF4 & 0.842 & 0.134 & Valid \\
\hline & PF5 & 0.848 & 0.134 & Valid \\
\hline & PF6 & 0.836 & 0.134 & Valid \\
\hline X2.3 & SS1 & 0.831 & 0.134 & Valid \\
\hline & SS2 & 0.890 & 0.134 & Valid \\
\hline & SS3 & 0.792 & 0.134 & Valid \\
\hline & SS4 & 0.934 & 0.134 & Valid \\
\hline X2.4 & SS1 & 0.863 & 0.134 & Valid \\
\hline & SS2 & 0.852 & 0.134 & Valid \\
\hline & SS3 & 0.859 & 0.134 & Valid \\
\hline & SS4 & 0.744 & 0.134 & Valid \\
\hline
\end{tabular}

Source: Data calculation SPSS 22

Table 2: Employee Performance: Service Excellence variable validity result

\begin{tabular}{|l|l|l|l|l|}
\hline Variable & Questions & Calculated r & Tabulated r & Note \\
\hline $\mathrm{Y}$ & 1 & 0.890 & 0.134 & Valid \\
\hline & 2 & 0.892 & 0.134 & Valid \\
\hline & 3 & 0.844 & 0.134 & Valid \\
\hline & 4 & 0.908 & 0.134 & Valid \\
\hline
\end{tabular}

From table 1 and 2 above, all variable indicators have result above 0.05 and therefore can be categorized as valid.

\subsection{Reliability Test}

An instrument is categorized reliable when the result is the same from any angle of measurement. Alpha Cronbach is usually used to test the reliability, If the alpha value is less than 0.6 it is categorized as unreliable, 0.7 is categorized as acceptable, and 0.8 as very good (Priyatno, 2017).

Table 3: Variables Reliability Result

\begin{tabular}{|l|l|l|l|}
\hline Variable & Cronbach's Alpha & N of Items & Note \\
\hline X1.1 & .848 & 3 & Reliable \\
\hline X1.2 & .858 & 3 & Reliable \\
\hline X1.3 & .901 & 3 & Reliable \\
\hline X1.4 & .920 & 3 & Reliable \\
\hline X2.1 & .880 & 5 & Reliable \\
\hline X2.2 & .908 & 6 & Reliable \\
\hline X2.3 & .885 & 4 & Reliable \\
\hline X2.4 & .885 & 5 & Reliable \\
\hline Y & .904 & 4 & Reliable \\
\hline Source: data calculation SPSS 22 & & \\
\hline
\end{tabular}

The table 3 above shows that the value of Cronbach alpha is above 0.6 so it is categorized as reliable.

4.3 Variable X1: Communicative Leadership (Communication Behavior)

Table 4: Communicative Leadership Descriptive Statistics

\begin{tabular}{|l|l|l|l|l|}
\hline & Min & Max & Mean & Std. Dev \\
\hline Initiating structure & 4.00 & 15.00 & 9.9495 & 2.61767 \\
\hline Facilitating work & 4.00 & 15.00 & 10.7850 & 2.28237 \\
\hline Relational dynamic & 3.00 & 15.00 & 8.6490 & 2.91511 \\
\hline Representing employees \& the unit & 3.00 & 15.00 & 9.7047 & 2.52938 \\
\hline Communicative leadership & 18.00 & 60.00 & 39.0881 & 7.06263 \\
\hline
\end{tabular}

Source: SPSS 22 Data Analysis 
Table 4, reveals that variable communicative leadership has 4 dimensions. The dimension with the highest mean was facilitating work while the lowest mean was relational dynamic. The respondents' answers can be various categorized, but dimension facilitating work was more clustered as it had the lowest standard deviation among all.

Table 5: MDS Leaders have applied Communicative Leadership

\begin{tabular}{|l|l|l|l|l|l|l|}
\hline & Strongly agree & Agree & Neutral & Disagree & Strongly disagree & Total \\
\hline Frequency & 106 & 220 & 295 & 115 & 36 & 772 \\
\hline Percent & 13.8 & 28.5 & 38.1 & 14.9 & 4.7 & 100 \\
\hline
\end{tabular}

Source: Researcher's excel data analysis 2020

The overall communicative leadership index was 66 which is categorized as poor according to MDS standards and respondents' response scale was 3.3 meaning moderate. Table 5 indicates that $38.1 \%$ of 772 respondents, which is 295 people stated they were neutral and $28.5 \%$ respondents or 220 people answered agreed that MDS leaders had applied communicative leadership.

4.4 Variable X2: Working Environment (Non-Physical WE)

Table 6: MDS Leaders have implemented good non-physical working environment

\begin{tabular}{|l|l|l|l|l|l|l|}
\hline & Strongly agree & Agree & Neutral & Disagree & Strongly disagree & Total \\
\hline Frequency & 96 & 229 & 296 & 111 & 39 & 772 \\
\hline Percent & 12 & 30 & 38 & 14 & 5 & 100 \\
\hline
\end{tabular}

Source: Researcher's excel data analysis 2020

Table 6 shows that 296 respondents or 38\% answered neutral, and 229 front liners or 30\% agreed that MDS had practiced good non-physical working environment. Its index was 67 meaning still poor, while the scale of respondents' response was 3.2 meaning moderate.

Table 7: Non-Physical Working Environment Descriptive Statistics

\begin{tabular}{|l|l|l|l|l|l|l|}
\hline & Range & Min & Max & Sum & Mean & Std. Deviation \\
\hline Goal Setting & 18.00 & 7.00 & 25.00 & 12721.00 & 16.4780 & 3.31538 \\
\hline Performance feedback & 22.00 & 8.00 & 30.00 & 15353.00 & 19.8873 & 4.91526 \\
\hline Supervisor support & 15.00 & 5.00 & 20.00 & 10488.00 & 13.5855 & 3.66909 \\
\hline Mentoring / coaching & 19.00 & 6.00 & 25.00 & 12345.00 & 15.9909 & 4.56697 \\
\hline Working environment & 71.00 & 29.00 & 100.00 & 50907.00 & 65.9417 & 12.11512 \\
\hline Valid N (listwise) & 772 & & & & & \\
\hline
\end{tabular}

Source: SPSS 22 Data Analysis

Table 7 above shows the non-physical working environment variable had 4 items. Performance feedback had the highest score as its mean (19.8873) was the highest among 4 other dimensions. The data of respondents' answers spread out relatively. The most clustered or consistent data was from goal setting as it had the least standard deviation among other dimension while performance feedback data had the most spread score as it had the highest standard deviation.

4.5 Employee Performance (Extra Role Behavior Performance - Service Excellence)

Table 8: MDS front liners have provided service excellence

\begin{tabular}{|l|l|l|l|l|l|l|}
\hline & Strongly agree & Agree & Neutral & Disagree & Strongly disagree & Total \\
\hline Frequency & 78 & 123 & 344 & 144 & 63 & 772 \\
\hline Percent & 10 & 16 & 51 & 15 & 8 & 100 \\
\hline
\end{tabular}

Source: Researcher's excel data analysis 2020

The survey showed that out of 772 respondents $51 \%$ of them or 344 respondents answered neutral, and 123 front liners or $16 \%$ agreed that they as the service providers of MDS had provided service excellence to customers. However, the index was only 61 meaning it was still poor. Whereas the respondents' response rate was 3.1 meaning moderate.

Table 9: Service Excellence Descriptive Statistics

\begin{tabular}{|l|l|l|l|l|l|l|}
\hline & Range & Min & Max & Sum & Mean & Std Deviation \\
\hline Y1.1 Delivering the promise & 4.00 & 1.00 & 5.00 & 2772.00 & 3.5907 & .88117 \\
\hline Y1.2 Personal touch & 4.00 & 1.00 & 5.00 & 1791.00 & 2.3199 & .79392 \\
\hline Y1.3 Going extra mile & 4.00 & 1.00 & 5.00 & 1902.00 & 2.4637 & .87328 \\
\hline Y1.4 Dealing with problem and queries & 4.00 & 1.00 & 5.00 & 2781.00 & 3.6023 & .88136 \\
\hline Employee Performance: providing SE & 14.00 & 5.00 & 19.00 & 9246.00 & 11.9767 & 3.07949 \\
\hline Valid N (listwise) & 772 & & & & & \\
\hline
\end{tabular}

Source: SPSS 22 Data Analysis 
Table 9 shows that the dependent variable had 4 items. The dimension with the highest mean was dealing with problems and queries: 3.6023 , meaning most of the respondents agreed that they had dealt with problems and queries for this dimension. Whereas the dimension of personal touch had the lowest mean: 2.3199 and it meant most of respondents disagreed. Another dimension that also had a mean score in the disagreed range (2.4637) which was going the extra mile. While delivering the promise and dealing well with problems and queries dimensions had scores in the agree zone (3.5907 \& 3.6023). Standard deviation scores of dimension in the Service Excellence variable were relatively close to each other, and yet there was a highest standard deviation that belonged to dealing with problems and queries dimension (.88136) meaning the data was spread out the most. Whereas the lowest standard deviation was personal touch dimension (.79392), meaning its data was the most consistent.

\subsection{Classical Assumption}

Figure 3: Normality Test Graph

Normal P.P Plot of Regression Standardized Residual

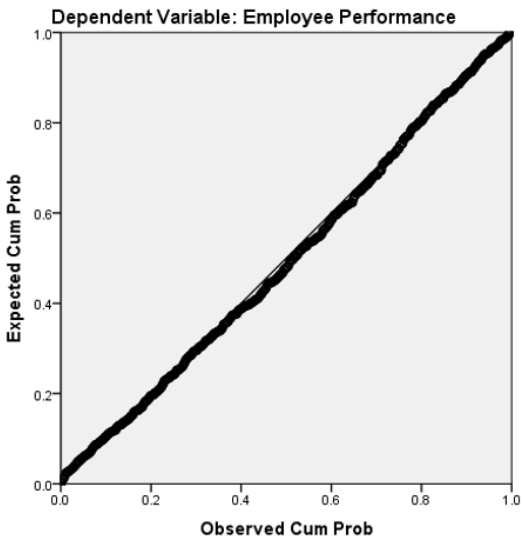

Source: SPSS 22 Statistics Result Table 11: Multicollinearity Test Result

\begin{tabular}{|ll|r|c|}
\hline \multirow{2}{*}{ Model } & \multicolumn{2}{|c|}{ Collinearity Statistics } \\
\cline { 3 - 4 } & \multicolumn{2}{|c|}{ Tolerance } & \multicolumn{1}{c|}{ VIF } \\
\hline 1 & (Constant) & & \\
& Communicative Leadership & .749 & 1.336 \\
& Working Environment & .749 & 1.336 \\
\hline
\end{tabular}

a. Dependent Variable: Employee Performance

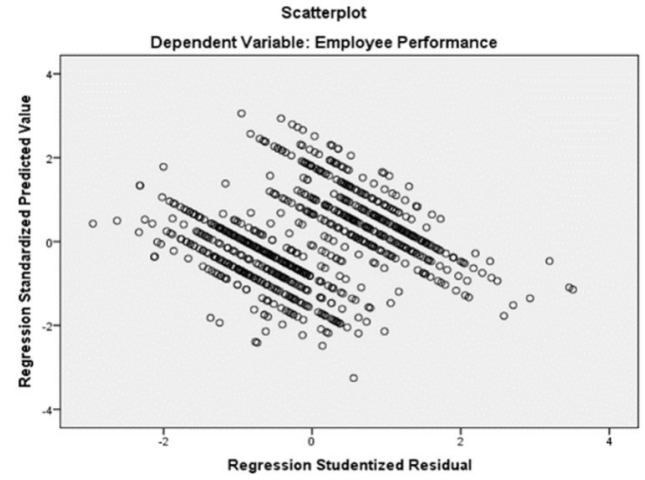

Source: SPSS 22 Statistics Result
Table 10: Normality Test Result

One-Sample Kolmogorov-Smirnov Test

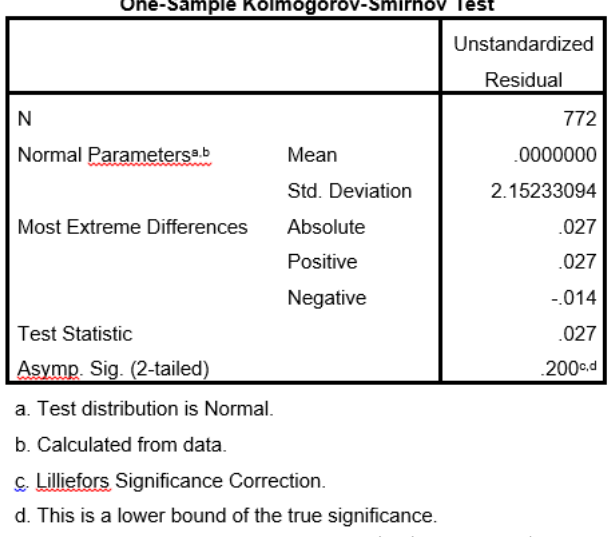

Source: SPSS 22 Statistics Result

Figure 4: Heterocedasticity Test Result

Source: SPSS 22 Statistics Result 


\subsection{Correlation Analysis}

Table 12: Correlation Analysis of X1 to Y

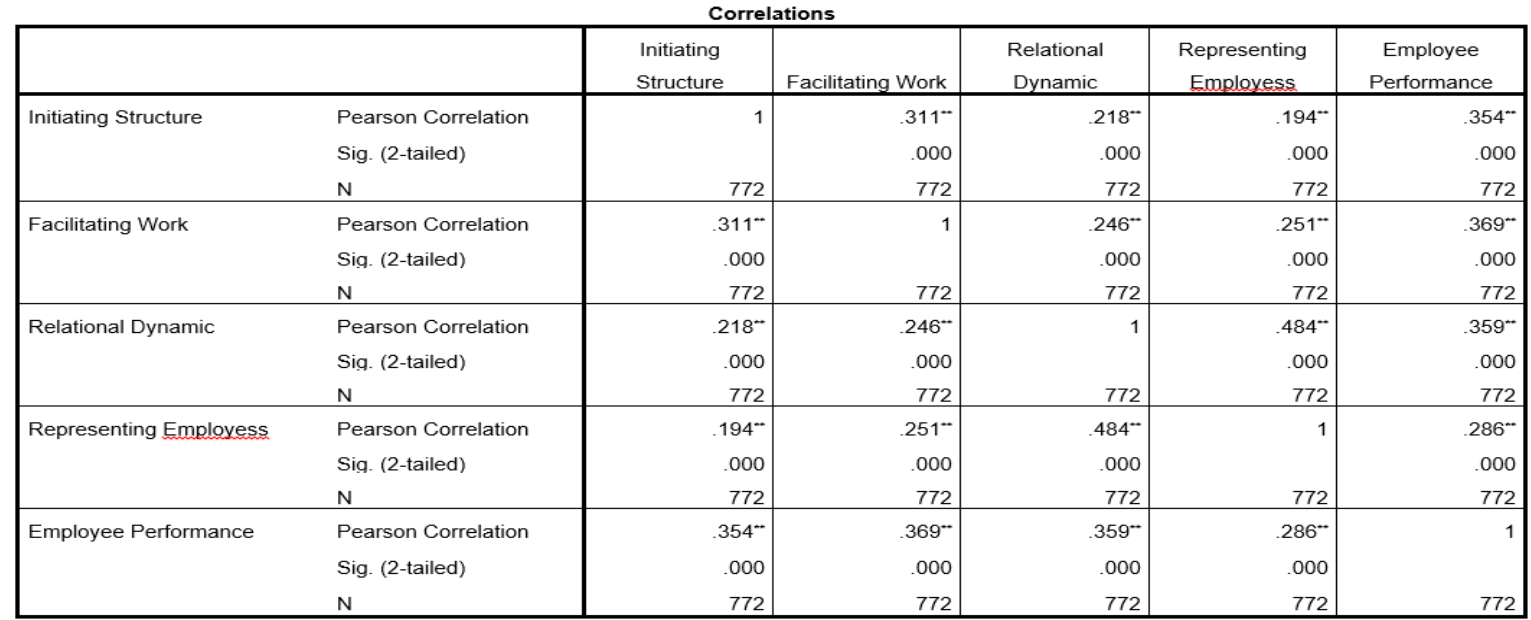

${ }^{* \star}$. Correlation is significant at the 0.01 level (2-tailed)

Source: SPSS 22 data analysis

Table 12 explains that Initiating Structure, Facilitating Work, Relational Dynamic, and Representing Employees and the Unit, all had weak correlations with Employee Performance, as their Pearson correlation values were below 0.41 and above 0.20 .

Table 13: Correlation Analysis of X2 to Y

\begin{tabular}{|c|c|c|c|c|c|c|}
\hline \multicolumn{7}{|c|}{ Correlations } \\
\hline & & Goal Setting & $\begin{array}{l}\text { Performance } \\
\text { Feedback }\end{array}$ & $\begin{array}{c}\text { Supervisor } \\
\text { Support }\end{array}$ & $\begin{array}{l}\text { Mentoring \& } \\
\text { Coaching }\end{array}$ & $\begin{array}{l}\text { Employee } \\
\text { Performance }\end{array}$ \\
\hline \multirow[t]{3}{*}{ Goal Setting } & Pearson Correlation & 1 & $297^{-}$ & $295^{-}$ & $.307^{-}$ & $.350^{-}$ \\
\hline & Sig. (2-tailed) & & .000 & .000 & .000 & .000 \\
\hline & $\mathrm{N}$ & 772 & 772 & 772 & 772 & 772 \\
\hline \multirow[t]{3}{*}{ Performance Feedback } & Pearson Correlation & $297^{-}$ & 1 & $.409^{-}$ & $.409^{-}$ & $.410^{-}$ \\
\hline & Sig. (2-tailed) & .000 & & .000 & .000 & .000 \\
\hline & $\mathrm{N}$ & 772 & 772 & 772 & 772 & 772 \\
\hline \multirow[t]{3}{*}{ Supervisor Support } & Pearson Correlation & $295^{*}$ & .409-" & 1 & $.537^{-}$ & $.567^{*}$ \\
\hline & Sig. (2-tailed) & .000 & .000 & & .000 & .000 \\
\hline & $\mathrm{N}$ & 772 & 772 & 772 & 772 & 772 \\
\hline \multirow[t]{3}{*}{ Mentoring \& Coaching } & Pearson Correlation & $307^{-1}$ & $409^{-\prime}$ & $.537^{-}$ & 1 & $.687^{*}$ \\
\hline & Sig. (2-tailed) & .000 & .000 & .000 & & .000 \\
\hline & $\mathrm{N}$ & 772 & 772 & 772 & 772 & 772 \\
\hline \multirow[t]{3}{*}{ Employee Performance } & Pearson Correlation & $350^{-1}$ & $410^{-1}$ & $567^{-}$ & $687^{-}$ & 1 \\
\hline & Sig. (2-tailed) & .000 & .000 & .000 & .000 & \\
\hline & $\mathrm{N}$ & 772 & 772 & 772 & 772 & 772 \\
\hline
\end{tabular}

Source: SPSS 22 data analysis

The table data above tells us that Goal Setting had the weakest correlation with Employee Performance as its Pearson correlation was 0.350. Performance Feedback and Supervisor Support were moderate while Mentoring and Coaching had the strongest correlation which was 0.687 .

Table 14: Correlation Analysis of X1 \& X2 to Y

\begin{tabular}{|c|c|c|c|c|}
\hline & & $\begin{array}{l}\text { Communicative } \\
\text { Leadership }\end{array}$ & $\begin{array}{c}\text { Working } \\
\text { Environment }\end{array}$ & $\begin{array}{l}\text { Employee } \\
\text { Performance }\end{array}$ \\
\hline \multirow[t]{3}{*}{ Communicative Leadership } & Pearson Correlation & 1 & $.520^{-*}$ & $.513^{-}$ \\
\hline & Sig. (2-tailed) & & .000 & .000 \\
\hline & $\mathrm{N}$ & 772 & 772 & 772 \\
\hline \multirow[t]{3}{*}{ Working Environment } & Pearson Correlation & $.520^{-}$ & 1 & $.707^{\circ}$ \\
\hline & Sig. (2-tailed) & .000 & & .000 \\
\hline & $\mathrm{N}$ & 772 & 772 & 772 \\
\hline \multirow[t]{3}{*}{ Employee Performance } & Pearson Correlation & $513^{*}$ & $.707^{*}$ & 1 \\
\hline & Sig. (2-tailed) & .000 & .000 & \\
\hline & $\mathrm{N}$ & 772 & 772 & 772 \\
\hline
\end{tabular}

$\approx \approx$. Correlation is significant at the 0.01 level (2-tailed).

Source: SPSS 22 data analysis 
Based on table 14, it shows that the Pearson correlation value of X1 (Communicative Leadership) was 0.501, meaning Communicative Leadership and Employee Performance had a moderate correlation whereas X2 (Working Environment) and Employee Performance had a strong relationship or correlation with Pearson as the correlation value was 0.693 .

4.8 Simple and Multiple Linear Regression Analysis

Table 15: Regression Result of Hypothesis 1

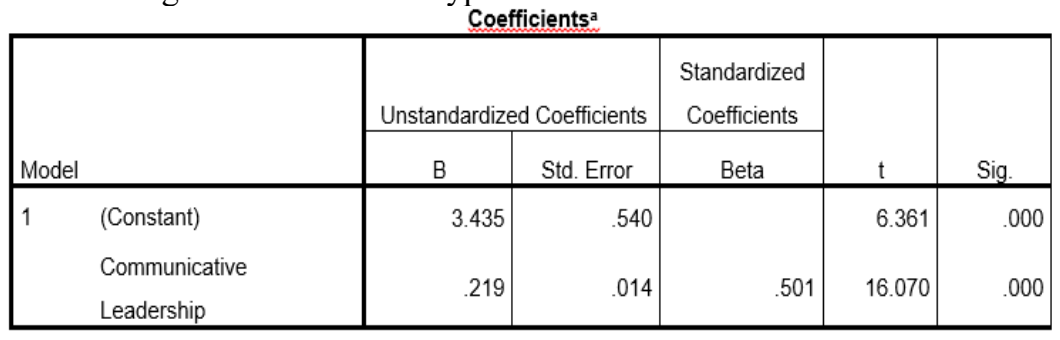

a. Dependent Variable: Employee Performance

Source: SPSS 22 data analysis

Table 16: Regression Result of Hypothesis 2

\begin{tabular}{|c|c|c|c|c|c|c|}
\hline \multirow[b]{2}{*}{ Mode } & & \multicolumn{2}{|c|}{ Unstandardized Coefficients } & \multirow{2}{*}{$\begin{array}{c}\text { Standardized } \\
\text { Coefficients } \\
\text { Beta } \\
\end{array}$} & \multirow[b]{2}{*}{$\mathrm{t}$} & \multirow[b]{2}{*}{ Sig. } \\
\hline & & $\mathrm{B}$ & Std. Error & & & \\
\hline \multirow[t]{2}{*}{1} & (Constant) & .365 & .443 & & .824 & .410 \\
\hline & Working Environment & .176 & .007 & .693 & 26.656 & .000 \\
\hline
\end{tabular}

a. Dependent Variable: Employee Performance

Source: SPSS 22 Data Analysis

Table 15 shows the regression equation: $\mathrm{Y}=3.435+0.219 \mathrm{X} 1$ which means the constant value $(\alpha)$ is 33.435 . If Communicative Leadership variable (X1) is zero (0), Employee Performance (Y) value is 3.435. The coefficient value $(\beta)$ of $\mathrm{X} 1$ is 0.219 and positive, meaning in every increase of Communicative Leadership, Employee Performance (Y) increased 0.219 .

Table 16 shows the regression equation: $\mathrm{Y}=0.365+0.176 \mathrm{X} 2$ which means the constant value $(\alpha)$ is 0.365 . If Working Environment variable (X2) is zero (0), Employee Performance (Y) value is 0.365. The coefficient value $(\beta)$ of $\mathrm{X} 2$ is 0.176 and positive, meaning in every increase of Communicative Leadership, Employee Performance $(Y)$ increased 0.176 .

Table 17: Multiple Regression Analysis Result

\begin{tabular}{|c|c|c|c|c|c|c|}
\hline \multicolumn{7}{|c|}{ Coefficientsa } \\
\hline \multirow{2}{*}{\multicolumn{2}{|c|}{ Model }} & \multicolumn{2}{|c|}{ Unstandardized Coefficients } & \multirow{2}{*}{$\begin{array}{c}\begin{array}{c}\text { Standardized } \\
\text { Coefficients }\end{array} \\
\text { Beta }\end{array}$} & \multirow[b]{2}{*}{$\mathrm{t}$} & \multirow[b]{2}{*}{ Sig. } \\
\hline & & $\mathrm{B}$ & Std. Error & & & \\
\hline \multirow[t]{4}{*}{1} & (Constant) & -1.410 & .498 & & -2.832 & .005 \\
\hline & Communicative & & & & & \\
\hline & Leadership & .090 & .013 & .205 & 7.052 & .000 \\
\hline & Working Environment & .150 & .007 & .590 & 20.245 & .000 \\
\hline
\end{tabular}

a. Dependent Variable: Employee Performance

Source: SPSS 22 data analysis

As shown in table 17 the regression equation is as follows: $\mathrm{Y}=-1.410+0.090 \mathrm{X} 1+0.150 \mathrm{X} 2$. It means constant value $(\alpha):-1,410$ and that if the Communicative Leadership variable (X1) and Working Environment variable values were 0, then Employee Performance (Y) was -1,410. The coefficients value ( $\beta$ ) for X1 was 0.090 and positive, meaning every time Communicative Leadership increased Employee Performance: service excellence would increase 0.090 with an assumption that $\mathrm{X} 2$ value remained unchanged. The coefficients value $(\beta)$ for $\mathrm{X} 2$ variable was 0.150 and positive, meaning every time $\mathrm{X} 2$ increased $\mathrm{Y}$ would increase 0.150 with an assumption that $\mathrm{X} 1$ value remained unchanged. 
Table 18: Determination Coefficient of X1 with Y

\begin{tabular}{|l|l|l|l|l|}
\hline Model & R & R Square & Adjusted R Square & Std. Error of the Estimate \\
\hline 1 & $.501^{\mathrm{a}}$ & .251 & .250 & 2.66660 \\
\hline
\end{tabular}
a. Predictors: (Constant), Communicative Leadership

b. Dependent Variable: Employee Performance

Source: SPSS 22 data analysis

Based on table 18, Communicative Leadership variable had a moderate coefficient correlation ${ }^{\circledR}$ which was 0.501, and coefficient determination $\left(\mathrm{R}^{2}\right)$ value was 0.251 meaning $25.1 \%$ of Employee Performance (Y) was influenced by communicative leadership, while the rest $74.9 \%$ was influenced by other factors that were not studied in the research.

Table 19: Determination Coefficient of X2 with Y

\begin{tabular}{|l|l|l|l|l|}
\hline Model & R & R Square & Adjusted R Square & Std. Error of the Estimate \\
\hline 1 & $.693^{\mathrm{a}}$ & .480 & .479 & 2.22228 \\
\hline
\end{tabular}

a. $\quad$ Predictors: (Constant), Working Environment

b. Dependent Variable: Employee Performance

Source: SPSS 22 data analysis

Table 19 shows that the Working Environment variable had a strong coefficient correlation ${ }^{\circledR}$ which was 0.693, and the coefficient determination $\left(\mathrm{R}^{2}\right)$ value was 0.480 meaning $48 \%$ of Employee Performance (Y) was influenced by Working Environment, while the rest $52 \%$ was influenced by other factors that were not studied in the research.

Table 20: Determination Coefficient of X1 and X2 with Y

\begin{tabular}{|l|l|l|l|l|}
\hline Model & R & R Square & Adjusted R Square & Std. Error of the Estimate \\
\hline 1 & $.715^{\mathrm{a}}$ & .512 & .510 & 2.15513 \\
\hline
\end{tabular}

c. Predictors: (Constant), Working Environment, Communicative Leadership

d. Dependent Variable: Employee Performance

Source: SPSS 22 data analysis

Based on table 20 above, $\mathrm{X} 1$ and $\mathrm{X} 2$ had a strong coefficient correlation ${ }^{\circledR}$ which was 0.715 , and the coefficient determination $\left(\mathrm{R}^{2}\right)$ value was 0.512 meaning $51.2 \%$ of Employee Performance $(\mathrm{Y})$ was influenced by Communicative Leadership (X1) and Working Environment (X2), While the rest $48.8 \%$ was influenced by other factors that were not discussed in the research.

\subsection{F Test}

Table 21: X1 F-test Result

\begin{tabular}{|c|c|c|c|c|c|c|}
\hline \multicolumn{7}{|c|}{ ANOVAa } \\
\hline & & Sum of Squares & $\mathrm{df}$ & Mean Square & $\mathrm{F}$ & Sig. \\
\hline \multirow[t]{3}{*}{1} & Regression & 1836.295 & 1 & 1836.295 & 258.242 & $.000^{\mathrm{b}}$ \\
\hline & Residual & 5475.285 & 770 & 7.111 & & \\
\hline & Total & 7311.580 & 771 & & & \\
\hline
\end{tabular}

a. Dependent Variable: Employee Performance

b. Predictors: (Constant), Communicative Leadership

Source: SPSS 22, Data Analysis

Table 21 shows a calculated $\mathrm{F}$ value of $258.242>\mathrm{F}$ table $3.854(\mathrm{df1}=2$; df2 =770) with significance of 0.000 . When calculated $\mathrm{F}$ value was greater than $\mathrm{F}$ table and its significance was less than 0.05 . The researcher can conclude this regression model was significant to predict Employee Performance with Communicative Leadership. In other words, the independent variable: Communicative Leadership (X1) influenced Employee Performance (Y).

Table 22: X2 F-test Result

\begin{tabular}{|ll|r|r|r|r|r|}
\hline \multicolumn{1}{|l|}{ Model } & & Sum of Squares & \multicolumn{1}{c|}{ df } & Mean Square & \multicolumn{1}{c|}{ F } & Sig. \\
\hline 1 & Regression & 3508.908 & 1 & 3508.908 & 710.516 & $.000^{\circ}$ \\
& Residual & 3802.672 & 770 & 4.939 & & \\
& Total & 7311.580 & 771 & & & \\
\hline
\end{tabular}

a. Dependent Variable: Employee Performance

b. Predictors: (Constant), Working Environment

Source: SPSS 22, Data Analysis

Table 22 shows a calculated $\mathrm{F}$ value of $710.516>\mathrm{F}$ table $3.854(\mathrm{df1}=2$; df2 $=770)$ with significance of 
0.000. The researcher concluded this regression model was significant to predict Employee Performance with the Working Environment. In other words, the independent variable: Working Environment (X2) influenced Employee Performance (Y).

Table 23: X1 \& X2 F-test Result

\begin{tabular}{|ll|r|r|r|r|r|}
\hline \multicolumn{1}{|l|}{ Model } & & Sum of Squares & \multicolumn{1}{c|}{ df } & Mean Square & F & \multicolumn{1}{c|}{ Sig. } \\
\hline 1 & Regression & 3739.901 & 2 & 1869.950 & 402.609 & $.000^{\mathrm{b}}$ \\
& Residual & 3571.679 & 769 & 4.645 & & \\
& Total & 7311.580 & 771 & & & \\
\hline
\end{tabular}

a. Dependent Variable: Employee Performance

b. Predictors: (Constant), Working Environment, Communicative Leadership

Source: SPSS 22 data analysis

Based on table 23, a calculated $F$ value of $402.609>\mathrm{F}$ table $3.007(\mathrm{dfl}=2$; df2 $=769)$ with significance of 0.000 . When the calculated $\mathrm{F}$ value was greater than $\mathrm{F}$ table and its significance was less than 0.05 , this means this regression model was significant to predict Communicative Leadership and Working Environment with Employee Performance. It is concluded that:

a. Ho3 Communicative Leadership (X1) and Non-Physical Working Environment (X2) do not influence Front liners' behavior performance: providing service excellence $(\mathrm{Y})$ is rejected

b. Ha3 Communicative Leadership (X1) and Working Environment (X2) simultaneously influenced Front liners' behavior Performance: providing service excellence $(\mathrm{Y})$ is accepted

4.10 t-Test

Table 24: X1 t-test Result

\begin{tabular}{|c|c|c|c|c|c|c|}
\hline \multicolumn{7}{|c|}{ Coefficients } \\
\hline \multirow{2}{*}{\multicolumn{2}{|c|}{ Model }} & \multicolumn{2}{|c|}{ Unstandardized Coefficients } & \multirow{2}{*}{$\begin{array}{c}\text { Standardized } \\
\text { Coefficients } \\
\text { Beta } \\
\end{array}$} & \multirow[b]{2}{*}{$\mathrm{t}$} & \multirow[b]{2}{*}{ Sig. } \\
\hline & & $\mathrm{B}$ & Std. Error & & & \\
\hline 1 & (Constant) & 3.435 & .540 & & 6.361 & .000 \\
\hline & Communicative & & 014 & & & \\
\hline & Leadership & & . 014 & .501 & 16.070 & .000 \\
\hline
\end{tabular}

a. Dependent Variable: Employee Performance

Source: SPSS 22 Data Analysis

Table 24 above shows that a calculated t value of Communicative Leadership variable (X1): $16.070>1.963$ of $\mathrm{t}$ table value $(\mathrm{df}=769)$. Whereas the $\mathrm{t}$ significance value was $0.000<0.05$ meaning:

a. Ho 1 Communicative Leadership (X1) does not influence Employee Performance (Y) is rejected.

b. Ha 1 Communicative Leadership (X1) positively and significantly influences Working Environment (Y) is accepted

Table 25: X2 t-test Result

\begin{tabular}{|c|c|c|c|c|c|c|}
\hline \multicolumn{7}{|c|}{ Coefficientsa } \\
\hline \multirow{2}{*}{\multicolumn{2}{|c|}{ Model }} & \multicolumn{2}{|c|}{ Unstandardized Coefficients } & \multirow{2}{*}{$\begin{array}{c}\text { Standardized } \\
\text { Coefficients } \\
\text { Beta } \\
\end{array}$} & \multirow[b]{2}{*}{$\mathrm{t}$} & \multirow[b]{2}{*}{ Sig. } \\
\hline & & $\mathrm{B}$ & Std. Error & & & \\
\hline \multirow[t]{2}{*}{1} & (Constant) & .365 & .443 & & .824 & .410 \\
\hline & Working Environment & .176 & .007 & .693 & 26.656 & .000 \\
\hline
\end{tabular}

a. Dependent Variable: Employee Performance

Source: SPSS 22 Data Analysis

Table 25 above shows that a calculated t value of Communicative Leadership variable (X1): $26.656>1.963$ of the $\mathrm{t}$ table value $(\mathrm{df}=769)$. Whereas the $\mathrm{t}$ significance value was $0.000<0.05$ meaning:

a. Ho 2 Working Environment (X2) does not influence Employee Performance (Y) is rejected.

b. Ha 2 Working Environment (X2) positively and significantly influences Working Environment (Y) is accepted

\section{Conclusions and Recommendations}

\subsection{Conclusions}

Based on the analyzed data gathered and the hypothesis tests conducted the researcher concluded that:

a. Communicative Leadership and Employee Performance correlation was weaker than the correlation of Working Environment and Employee Performance. 
b. Representing Employees and the unit was the dimensions in Communicative Leadership (X1) that had the weakest correlation with Employee Performance (Y), while Facilitating Work dimension had the strongest correlation with Employee Performance (Y).

c. In Non-Physical Working Environment variable (X2) Mentoring and Coaching dimension had the strongest correlation with Employee Performance whereas Goal Setting dimension had the smallest or weakest one.

d. When X1 (Communicative Leadership) was combined with X2 (Working Environment), the correlation with Employee Performance was stronger than when the independent variables stood alone.

e. Working Environment had a stronger influence on Employee Performance.

f. Personal touch dimension in Service Excellence had the lowest score.

\subsection{Recommendations}

Theoretical recommendations: In the future research it is suggested that another study be done to:

a. Analyze how communicative leadership and non-physical working environment are implemented in department stores

b. Analyze the study results about communicative leadership, working environment and employee performance quantitatively and qualitatively (mixed method).

Practical recommendations:

a. The company should improve communicative leadership behaviors implementation among all leaders in the organization by focusing on the dimensions especially representing the employees and the unit one in order to increase employee performance.

b. The company should improve the internal communication system especially in conveying important messages from the management to front liners.

c. The company's attention should be focused on the Relational dynamic as it had the lowest mean score among other dimensions in communicative leadership.

d. The company should take immediate action to enhance the implementation of the Goal Setting dimension as it is at the core of where the company will lead to and yet it had the weakest correlation with employee performance in working environment variable (X2).

e. The company's attention should also be focused on the Supervisor Support as it had the lowest mean score among other dimensions in the working environment.

f. The company should also start implementing more personal touch and extra mile dimensions to provide better service

\section{References}

Alvero, A. M., Bucklin, B. R., \& Austin, J. (2011). An Objective Review of the Effectiveness and Essential Characteristics of Performance Feedback in Organization Setting. Journal of Organization Behavior Management, 21(1); 2-29.

Asif, M. (2014, April 18). A critical review of service excellence models: towards developing an integrated framework Qual Quant 49, 763-783. https://doi.org/10.1007/s11135-014-0022-y

Brady, M. K., \& Cronin, J. J. (2001). Customer Orientation effect on Customer Service Perceptions and Outcome Behaviours. Journal of Service Research, 3(3), 241-251.

Burke, Michael, J., Borucki, C. C., \& Hurley, A. E. (1992). Reconceptualizing Psychological Climate in a Retail Service Environment: A Multiple-Stakeholder Perspective. Journal of Applied Psychology, 77 (5): 717-729. https://doi.org/10.1177\%2F0143831X09351212

Busck, O., Knudsen, H., \& Lind, J. (2010). The transformation of employee participation: Consequences for the work environment. Economic and Industrial Democracy 31, 285-305.

Chandrasekar, K. (2011). WORKPLACE ENVIRONMENT AND ITS IMPACT ON ORGANIZATIONAL PERFORMANCE IN PUBLIC SECTOR ORGANISATIONS. International Journal of Enterprise Computing and Business Systems.

Creswell, J. W. (2012). Planning, Conducting and Evaluating Quantitative and Qualitative Research. Boston: Pearson Education Inc.

Creswell, J. W. (2014). Research Design: Qualitative, Quantitative, and Mixed Methods Approaches. Los Angeles: Sage Publication.

Creswell, J. W., \& Plano Clark, V. L. (2011). Designing and Conducting Mixed Methods Research. Thousand Oaks CA: Sage Publication.

Davis, F. R. (1989). How Companies Define Their Mission. Long Range Planning, 22(1); 90-97.

Douglas, C. A. (1997). Formal Mentoring in Organization. Greensboro N.C: Center for Creative Leadership.

Erez, M., Earley, P. C., \& Hulin, C. L. (2017). The Impact of Participation on Goal Acceptance and Performance. Academy of Management Journal, 28 (1).

Frey, K. A., Leighton, J. A., \& Cecala, K. K. (2005). Buidling a Culture of service Excellence. The Physician 
Executive, 31(6); 40-44.

Hall, A. T., Zinko, R., Perryman, A. A., \& Ferris, G. R. (2009). Organizational Citizenship Behavior and Reputation: Mediators in the Relationship Between Accountability and Job Performance and Satisfaction. Journal of Leadership and Organizational Studies, 15(4); 381-392.

Hamrin, S. (2016). Communicative Leadership: Fostering Co-worker Agency in Two Swedish Business Organization. Corporate Communication: An International Journal, 21(2); 213-229.

Haynes, B. P. (2008). An Evaluation of the Impact of the Office Environment on Productivity. Journal of Facilities, $25(5 / 6) .178-19$.

Heale, R., \& Twycross, A. (2015). Validity and Reliability in Quantitative Studies. Evidence Based Nursing Online First. http://dx.doi.org/10.1136/eb-2015-102129

Hopkin-Thompson, P. A. (2000). Colleagues Helping Collegues: Mentoring and Coaching. National Association of Secondary School Principals, 84(617); 29-36.

Johansson, C., Miller, V. D., \& Hamrin, S. (2011). Theories, Concepts, and Central Communication Behaviors. Sundsvall: DEMICOM.

Johansson, C., Miller, V. D., \& Hamrin, S. (2014). Conceptualizing communicative leadership. Corrporate Communication: An International Journal, 19(2), 147-165.

Johnston, R. (2004). Towards better understanding of service excellence. Managing Service Quality: an International Journal, 14(2/3): 124-133.

Johnston, R. (2007). Insight into Service Excellence. In M. H. Gouthier, C. Coenen, H. S. Schulze, \& C. Wegmann, Service Excellence als Impulsgeber (pp. 17-35). Gabler.

Kottke, J., \& Sharafinski, C. E. (1988). Measuring Perceived Supervisory and Organizational Support. Educational and Psychological Measurement, 48, 1075-1079.

Leblebici, D. (2012). Impact of Workplace Quality on Employee's productivity: Case Study of a Bank in Turkey. Journal of Business, Economics \& Finance, 1(1); 2146-7943.

Matahari Department Store (2018). 2017 Annual Report Matahari Department Store. Available at investor.matahari.co.id/sites/default/files/2018-11/ar-2017.pdf (accessed: 21 February 2018).

Matahari Department Store (2019). 2018 Annual Report Matahari Department Store. Available at investor.matahari.co.id/sites/default/files/2019-4/ar-2018.pdf (accessed: 14 February 2019).

Matahari Department Store (2018). 2017 Mystery Shopping Report. Jakarta: Matahari Department Store.

Matahari Department Store (2018). 2017 Voice of Customers Report. Jakarta: Matahari Department Store.

Modaff, D. P., DeWine, S., \& Butler, J. (2007). Organizational Communication: Foundation, Challenges, and Misunderstanding. ( $2^{\text {nd }}$ edition) Ohio: Pearson.

Ollukkaran, B. A., \& Gunaseelan, R. (2012). A STUDY ON THE IMPACT OF WORK ENVIRONMENT ON EMPLOYEE PERFORMANCE. Namex International Journal of Management Research, 2; 2.

Oswald, A. (2012, November). THE EFFECT OF WORKING ENVIRONMENT ON WORKERS PERFORMANCE: THE CASE OF REPRODUCTIVE AND CHILD HEALTH CARE PROVIDERS IN TARIME DISTRICT. Muhimbili University of Health and Allied Sciences. Tanzania, Africa: Muhimbili University of Health and Allied Sciences. http://hdl.handle.net/123456789/592

Parsloe, E., \& Leedham, M. (2009). Coaching and Mentoring Practical Conversations to Improve Learning. ( $2^{\text {nd }}$ edition) London: Kogan Page.

Podsakoff, P. M., Mackenzie, S. B., Paine, J. B., \& Bachrach, D. G. (2000). Organizational citizenship behaviours: a critical review of theoritical and empirical literature and suggestions for future research . Journal of Management, 26(3), 513-563.

Podsakoff, P. M., Todor, W. D., \& Schuler, R. S. (1983). Leader Expertise is a Moderator of the Effect of Instrumental and Supportive Leader Behavior. Journal of Management, 9, 173.

Priyatno, D. (2017). Panduan Praktis Olah Data Menggunakan SPSS. Yogyakarta: Penerbit ANDI.

Prue, D. M., \& Fairbank, J. A. (1981). Performance Feedback in Organization Behavior Management. Journal of Organizational Behavior Management, 3(1).

Rashid, N. M., Sah, N. F., Ariffin, N. M., Ghani, W. W., \& Yunus, N. N. (2016). The Influence of Bank's Frontlines' Personality Traits on Job Performance. Procedia Economics and finance, 37: 65-72.

Rust, R., \& Oliver, R. (2000). Should we delight the customer? Journal of the Academy of Marketing Science, $28(1) ; 86-94$

Stallworth, J., \& Kleiner, B. (1996). Recent development in office design. Journal of Facilities, 14; 34-42.

Tetteh, E. K., Asiedu, C., Odei, G. A., Afful, C. B., \& Akwaboah, L. (2012, June). WORK ENVIRONMENT AND ITS IMPACT ON EMPLOYEE'S PERFORMANCE (A CASE STUDY OF PRODUCE BUYING COMPANY, KUMASI). Retrieved from Bachelor of Business Administration - Thesis / Dissertation: http://hdl.handle.net/123456789/37

Yap, J. E., Bove, L. L., \& Beveland, M. B. (2009). Exploring the effect of different reward program on in-role and extra role performance of retail sales associates. Qualitative Market Research: An International Journal, 
12(3), 279-294.

Yoon, M. H., Beatty, S. E., \& Suh, J. (2001). The efffect of work climate on critical employee and customer outcome: An employee-level analysis. International Journal of Service Industry Management, 12(5): 500521.

Zeithaml, V. A., Prasuraman, A., \& Berry, L. L. (1990). Delivering Quality Service Balancing Customers Perception and Expectation. New York: The Free Press. 